\title{
Analysis of immune responses in genital tracts of mice immunised with purified ribosomal fractions of Neisseria gonorrhoeae
}

\author{
EIJI KITA AND SHUZO KASHIBA \\ From the Department of Bacteriology, Nara Medical College, Kashihara City, Japan
}

SUMMARY Immunisation of ddY mice with the purified ribosomal fraction of Neisseria gonorrhoeae was found to protect against intravaginal challenge with homologous organisms. This protection correlated with the presence of bactericidal antibody to purified ribosomal fraction in serum as well as in vaginal secretions. Analysis of the vaginal fluids from control mice and those immunised with purified ribosomal fraction showed that the enhanced elimination of gonococci in immune mice might be because of an early response of leucocytes generated by the reaction mediated by antibody and complement. Absorption studies showed that there was at least one major protective antigen in purified ribosomal fraction, other than cell surface substances such as lipopolysaccharide, outer membrane proteins, and pili. Bactericidal assays mediated by antibody and complement showed that matched samples of serum and vaginal fluid from immune mice had comparable gonococcidal activity, which was augmented by the effect of progesterone. Although delayed hypersensitivity was produced in immune mice that were resistant to $N$ gonorrhoeae, the exact role of cellular immunity could not be clarified in this study. These results suggest that antibody to purified ribosomal fraction plays a major part in protection against gonococcal infection in the genital tract, and that such protection may entail both cellular immunity and hormonal changes.

\section{Introduction}

The development of practical models of infection with Neisseria gonorrhoeae in laboratory animals ${ }^{12}$ and in chimpanzees ${ }^{3}$ has appreciably advanced our understanding of the immunobiology of this organism. We have reported a mouse model for the study of gonococcal genital infection, ${ }^{4}$ and showed that female ddY mice were sensitive to genital infection with gonococci during the preovulatory period of the oestrous cycle. In recent years, the subcutaneous chamber model in guinea pigs has been the most widely used to monitor the immune response to gonococcal infection. ${ }^{56}$ Although the subcutaneous chambers are sites at which humoral immunity to experimental infection can be analysed, the site of infection is very different from that of natural infection in man. One of the important factors affecting the susceptibility to enhanced infection in women is the effect of reproductive hormones in the

Address for reprints: Dr E Kita, Department of Bacteriology, Nara Medical College, 840 Shijyocho, Kashihara City, Nara 634, Japan

Accepted for publication 13 December 1983 genital tract. ${ }^{7}$ Our previous work using the mouse uterus as the site of infection showed the preovulatory stage to be the most suitable for intravaginal inoculation of gonococci, because at this stage the effects of polymorphonuclear leucocytes and progesterone are absent.

The present study was undertaken to investigate the genital immune responses in mice immunised with ribosomal vaccine.

\section{Materials and methods}

MICE

Female ddY mice 5 to 6 weeks old (Shizuoka Agricultural Cooperative Association for Laboratory Animals, Shizuoka, Japan) were used for all experiments. They were fed a commercial laboratory animal diet and water ad libitum. The stages of their oestrous cycles were determined by conventional vaginal smear techniques ${ }^{89}$ as reported before. ${ }^{4}$

\section{BACTERIA}

The PH2 $(\mathrm{P}++\mathrm{Tr})$ strain of $N$ gonorrhoeae used in this study was a penicillin sensitive isolate from the human genital tract. Characteristics of strain PH2 
have been described previously. ${ }^{4}$ Gonococci were passed serially through mice to maintain their virulence. They were also cultured on GC agar base supplemented with isovitalex (BBL, Microbiology Systems, Cokeysville, Maryland, USA) for about 20 hours at $37^{\circ} \mathrm{C}$ in a moist candle jar. Identification of cultures of $N$ gonorrhoeae by colony morphology, oxidase reaction, and Gram stain was confirmed by sugar fermentation tests. Gonococci from plates with more than $95 \%$ type 2 colonies, as determined by the technique and criteria of Kellogg et al, ${ }^{10}$ were used for challenge. Organisms were preserved by the gelatin disc method as described by Yamai et al. ${ }^{11}$

We grew gonococci for experiments in liquid medium containing $2 \%(w / v)$ tryptose (Difco Laboratories, Detroit, Michigan, USA), $0 \cdot 4 \%$ dipotassium phosphate, $0 \cdot 1 \%$ potassium biphosphate, $0.5 \%$ sodium chloride, and $0.1 \%$ soluble starch (Difco). After autoclaving and immediately before use we added $1 \%(\mathrm{w} / \mathrm{v}$, final concentration) glucose, $0.04 \%$ sodium bicarbonate, and $0.01 \%$ cocarboxylase (thiamine pyrophosphate chloride, Sigma Chemical Co, St Louis, Missouri, USA) and sterilised the medium by filtration through a type HA $0.45 \mu \mathrm{m}$ grid membrane filter (Millipore, Bedford, Massachusetts, USA). Broth cultures were grown at $37^{\circ} \mathrm{C}$ with continuous revolution after the culture bottle had been tightly capped with a rubber stopper.

\section{PREPARATION OF THE PURIFIED RIBOSOMAL VACCINE}

We prepared the ribosomal vaccine by the method of Kita and Kashiba, ${ }^{12}$ and purified it by affinity chromatography using Sepharose conjugates of antibody to outer membrane complex as previously described. ${ }^{13}$ Briefly, the antigens that cross reacted with antibodies to outer membrane complex were removed from the ribosomal fraction by passing it over a $15 \mathrm{ml}$ column containing conjugated Sepharose 4B. The fraction was then pooled, dialysed, lyophilised, and stored at $-70^{\circ} \mathrm{C}$ until used. The ribosomal fraction obtained by affinity chromatography was designated the purified ribosomal fraction. Antiserum to purified ribosomal fraction prepared in rabbits did not react with envelope components of $N$ gonorrhoeae strain PH2 in the immunodiffusion test.

The ratio of ribonucleic acid (RNA) to protein was $2: 14$, and endotoxin was not detected by a limulus lysate coagulation test. The 2-keto-3-deoxyoctonate was not detectable in the purified ribosomal fraction by the method of Karkhians et al. ${ }^{14}$

\section{GONOCOCCAL INFECTION IN THE GENITAL} TRACT

Gonococci grown in the liquid medium were suspended at a concentration of $10^{8}$ colony forming units (cfu) $/ \mathrm{ml}$ in trypticase soy broth prewarmed at $37^{\circ} \mathrm{C}$, and kept at $37^{\circ} \mathrm{C}$ until inoculated. The gono- $<$ coccal suspension $(0.01 \mathrm{ml})$ was inoculated into the vagina with a sterile tip on a micropipette (Pippet $\frac{\mathbb{D}}{\square}$ man) as previously described. ${ }^{4}$ Mice were inoculated in the late proestrous or early oestrous stages, andes. one week after inoculation were killed for cultures of uterine specimens. The uterine bodies were removed, $\bar{\omega}$ resected, and homogenised in $0.1 \mathrm{ml}$ sterile trypticase soy broth. The homogenate was centrifuged at $100 \times g$ for five minutes to sediment cell debris. The supernatant $(0.05 \mathrm{ml})$ was cultured on GC agar plates with and without $1 \%$ VCN (vancomycin-ब colistin-nystatin). After overnight incubation at $37^{\circ} \mathrm{C}$ ㄹ in a candle jar, the colonies formed on plates weres identified as $N$ gonorrhoeae by Gram stain andoxidase test, and their identity was confirmed by a. sugar fermentation test.

PREPARATION OF ANTIGENS USED FOR PHA $N \underset{\omega}{\omega}$ Outer membrane was isolated by the metrof? described by Wolf-Watz et al. ${ }^{15}$ Crude outeros membrane fraction obtained by centrifuging cat $^{\circ}$ $280000 \times g$ for 70 hours using sucrose dengly + gradient $(65 \%-40 \%)$ was pooled after centrifuging $N$ several times, and was lyophilised after dialy@s. 6 Gonococcal pilus preparation was isolated by the응 standard purification method described by Brintonte $t$. $a l{ }^{16}$ Lipopolysaccharide was extracted from whole cells by the hot phenol method of Westphal ânde Jann, ${ }^{17}$ digested with pronase $(50 \mathrm{mg} / 1$ protease frofic Streptomyces griseus, Sigma) at $40^{\circ} \mathrm{C}$ for four houos, and heated at $100^{\circ} \mathrm{C}$ for five minutes to stop the reaction. The reacted lipopolysaccharide was centri- -0 fuged at $100000 \times g$ for 30 minutes, washed several + times, and finally suspended in saline.

IMMUNISATION WITH RIBOSOMAL VACCINE Mice were immunised subcutaneously with an app priate amount of purified ribosomal fraction.

\section{SERUM ANTIBODY TITRES}

Specimens of serum were obtained from mice on days $0,7,14$, and 28 after the final immunisation. $\overline{\bar{O}}$ Serum collected from each mouse was frozen and 3 stored at $-70^{\circ} \mathrm{C}$ until tested. Each serum sample was examined for the presence of antibodies against gonococcal antigens, and for the bactericidal activity against the challenge organism. Antibody titres weres? measured by the passive haemagglutination test as previously described, ${ }^{13}$ using sheep red blood cells coated with purified ribosomal fraction, pili, outer. membrane, and lipopolysaccharide as passive응 haemagglutination test antigens.

Bactericidal activity was measured by the method 0 of Wannemuehler $e t a^{6}$ with a slight modification. $N$ 을 gonorrhoeae $\mathrm{PH} 2$ type 2 was grown in the liquid $D$ 
medium, and cells were then washed with warm $\left(37^{\circ} \mathrm{C}\right)$ phosphate buffered saline (PBS) containing $0.5 \%$ glucose, $0.01 \mathrm{~mol} / 1$ magnesium chloride, and $0.01 \%$ fetal bovine serum. The cells were diluted to $10^{6} \mathrm{cfu} / \mathrm{ml}$ in RPMI 1640 (Gibco Laboratories, Grand Island, New York, USA). After it had been inactivated at $56^{\circ} \mathrm{C}$ for 30 minutes serum was serially (twofold) diluted in RPMI 1640 by using microtitre U plates, and the same volume of the cell suspension $(50 \mu \mathrm{l})$ was added to each well. A $50 \mu \mathrm{l}$ volume of a $1 / 10$ dilution of normal guinea pig serum used as a source of complement was added to the reaction mixture, which was then incubated at $37^{\circ} \mathrm{C}$ in a carbon dioxide chamber for 90 minutes while being shaken. Samples ( $25 \mu \mathrm{l}$ each) were plated in triplicate on agar plates. All plates were incubated at $37^{\circ} \mathrm{C}$ in a candle jar for 24 hours. Bactericidal activity was expressed as the maximum dilution yielding a $90 \%$ reduction in cfu when compared with corresponding controls, which lacked complement.

\section{VAGINAL POLYMORPHONUCLEAR LEUCOCYTE} RESPONSE DURING INFECTION

Total leucocyte counts in vaginal washing fluid were made with a haemocytometer at 12 hour intervals after challenge. The vaginal wash fluid was obtained from immune mice and pooled for measurement of bactericidal activity. The pooled fluid was centrifuged at $400 \times g$ for 10 minutes, concentrated by ultrafiltration, and sterilised by a membrane filter. Bactericidal assay of the vaginal wash fluid was performed in the same way as with the serum.

\section{DELAYED FOOTPAD TEST}

Mice immunised with ribosomal vaccine were tested by the footpad test for delayed hypersensitivity. Ribosomal proteins extracted by the method of Fogel and Sypherd ${ }^{19}$ were used as the eliciting antigen, and a $25 \mu \mathrm{l}$ volume of solution containing protein $100 \mathrm{mg} / \mathrm{l}$ was injected intradermally into the right hind footpad. Footpad thickness was measured 48 hours later, and any increase in thickness was corrected for by deducting the increase in thickness of the control left hind footpad, which had been injected with saline.

\section{ABSORPTION STUDY}

Samples of serum and vaginal fluid obtained from immune mice were absorbed by incubation with sheep red blood cells coated with antigen suspended in two volumes of serum or vaginal fluid for one hour at $37^{\circ} \mathrm{C}$ with slow shaking, and were then kept at $4^{\circ} \mathrm{C}$ overnight. The absorbed samples were centrifuged at $1200 \times g$ for 15 minutes, and the absorption procedure was repeated twice.

\section{Results}

PROTECTION AGAINST GONOCOCCAL UTERINE INFECTION BY PURIFIED RIBOSOMAL FRACTION Our previous work showed that an inoculum size of $10^{6}$ gonococci was optimal for the production of uterine endometritis in mice, and that the infectivity, as measured by the percentage of culture positive uterine specimens one week after challenge, was almost $100 \%$, regardless of the stage of the oestrous cycle. In this study the minimum inoculum dose required to establish uterine endometritis in mice was found to be $10^{4} \mathrm{cfu}$ in the late proestrous stage (data not shown).

Mice were immunised subcutaneously with different amounts of purified ribosomal fraction and intravaginally challenged 10 days after immunisation with $10^{6}$ cfu of strain PH2. Table I shows that the minimum effective dose required to achieve $90 \%$ protection was $40 \mu \mathrm{g}$ per mouse.

TABLE I Protection of purified ribosomal fraction against uterine infection

\begin{tabular}{lc}
\hline $\begin{array}{l}\text { Immunising dose* } \\
(\mu g \text { protein) }\end{array}$ & $\begin{array}{l}\text { Protection }(\%) t \\
\text { on day } 7\end{array}$ \\
\hline 5 & $25(\mathrm{p}>0 \cdot 1)$ \\
10 & $50(\mathrm{p}>0 \cdot 01)$ \\
20 & $65(\mathrm{p}<0 \cdot 01)$ \\
40 & $90(\mathrm{p}<0.001)$ \\
60 & $100(\mathrm{p}<0.001)$ \\
Saline (control) & 5 \\
\hline
\end{tabular}

*Each group consisted of 20 mice immunised subcutaneously with the indicated dose. Mice in the late proestrous stage were challenged intravaginally with $10^{6} \mathrm{cfu}$ of strain $\mathrm{PH2} 10$ days after immunisation. Data were obtained fróm two separate experiments. tNo of mice with uterine specimens yielding negative cultures, expressed as percentage of mice studied. P values with respect to controls (saline) were calculated by Fisher's exact test.

\section{HUMORAL IMMUNE RESPONSE}

Subcutaneous immunisation with $20 \mu \mathrm{g}$ of purified ribosomal fraction elicited a high antibody response as early as $\mathbf{1 0}$ days after a single injection of the fraction. Activity of antibody to purified ribosomal fraction reached a maximum two to three weeks after immunisation. Antibodies against outer membrane and pilous antigens could not be measured in serum samples of mice immunised with purified ribosomal fraction. Samples of serum and vaginal fluid obtained from immune mice gave a single precipitin band which formed a line of identity when tested by immunodiffusion against purified ribosomal fraction. No visible line was formed against lipopolysaccharide, pilous, or outer membrane preparations.

\section{BACTERICIDAL ACTIVITY OF IMMUNE SERUM} AND VAGINAL FLUID

Table II shows bactericidal activity of samples of serum and vaginal fluid from mice immunised with 
TABLE II Bactericidal activity of vaginal fluid and serum from mice immunised with gonococcal purified ribosomal fraction

\begin{tabular}{|c|c|c|c|c|}
\hline \multirow[b]{2}{*}{ Immunogen* } & \multirow[b]{2}{*}{ Oestrous stage when samples taken } & \multicolumn{2}{|c|}{ Bactericidal activity† } & \multirow[b]{2}{*}{ Protection (\%)市 on day 7} \\
\hline & & Serum & Vaginal fluid & \\
\hline Purified ribosomal fraction & $\begin{array}{l}\text { Late proestrous } \\
\text { Early oestrous } \\
\text { Early metoestrous } \\
\text { Dioestrous }\end{array}$ & $\begin{array}{l}1 / 8 \\
1 / 8 \\
1 / 16 \\
1 / 32\end{array}$ & $\begin{array}{l}1 / 16 \\
1 / 16 \\
1 / 32 \\
1 / 64\end{array}$ & $\begin{array}{r}60(\mathrm{p}<0.001) \\
65(\mathrm{p}<0.001) \\
90(\mathrm{p}<0.001) \\
100(\mathrm{p}<0.001)\end{array}$ \\
\hline Saline (control) & $\begin{array}{l}\text { Late proestrous } \\
\text { Early oestrous } \\
\text { Early metoestrous } \\
\text { Dioestrous }\end{array}$ & $\begin{array}{l}1 / 2 \\
1 / 2 \\
1 / 4 \\
1 / 4\end{array}$ & $\begin{array}{l}1 / 2 \\
1 / 2 \\
1 / 4 \\
1 / 8\end{array}$ & $\begin{array}{l}0 \\
0 \\
5 \\
5\end{array}$ \\
\hline
\end{tabular}

* Groups of $\mathbf{4 0}$ mice were immunised subcutaneously with $20 \mu \mathrm{g}$ purified ribosomal fraction and serum and vaginal fluid collected from 20 . The other 20 were challenged intravaginally with $10^{\circ} \mathrm{cfu}$ of strain PH2 and protection was calculated by uterine culture on day 7 . Data were obtained from two separate experiments.

+Bactericidal activity expressed as the maximum dilution yielding a $90 \%$ reduction in cfu when compared with corresponding controls lacking complement.

¥No of mice with uterine specimens yielding negative cultures, expressed as percentage of mice studied. $P$ values with respect to the corresponding controls (saline) were calculated by Fisher's exact test.

purified ribosomal fraction. Serum samples from immunised mice were bactericidal at titres ranging from $1 / 8$ to $1 / 32$, while those from control mice injected with saline had titres of less than $1 / 4$. The degree of bactericidal activity of immune serum correlated with the stage of oestrous. Serum from mice in early metoestrous or dioestrous stages showed more than a twofold increase in bactericidal activity compared with that from mice in late proestrous or early oestrous stages. These findings were true of the bactericidal activity of vaginal fluid, and the degree of bactericidal activity in it was a little higher than in serum. Protection was paralleled by the bactericidal activity in samples of serum and vaginal fluid. These data indicated that vaginal fluid as well as serum from mice immunised with purified ribosomal fraction had sufficient bactericidal activity to reduce infectivity. The fact that the degree of bactericidal activity changes with mouse oestrous cycles, however, might suggest that gonococcidal activity, which was conferred by antibody to purified ribosomal fraction, entailed hormonal activity.

Table III shows absorption study results with appreciably reduced bactericidal activity in both samples after they had been absorbed with purified ribosomal fraction. Absorption with lipopolysaccharide, pilous, or outer membrane antigens did not affect the bactericidal activity of either sample. This strongly indicated that purified ribosomal fraction was one of the major antigens capable of evoking the gonococcidal antibody that was secreted into the genital tract.

\section{ANALYSIS OF CELLULAR RESPONSES IN THE GENITAL TRACT}

To assess initial changes in the genital tract of mice immunised with purified ribosomal fraction or saline, we studied vaginal polymorphonuclear
TABLE III Bactericidal activity of serum and vaginal fluid after absorption with gonococcal antigens

\begin{tabular}{llll}
\hline Samples* & Absorbed witht & $\begin{array}{l}\text { Bactericidal } \\
\text { activity }\end{array}$ & $\leqslant 1 / 8$ \\
\hline Serum & Purified ribosomal fraction & $1 / 32$ \\
& Lipopolysaccharide & $1 / 32$ \\
& Outer membrane & $1 / 32$ \\
& Pili & $1 / 32$ \\
& Not absorbed & $1 / 16$
\end{tabular}

* Each sample was collected from mice in the dioestrous stage. †Each sample was absorbed with sheep red blood cells coated wit purified ribosomal fraction, lipopolysaccharide, outer membrans and pili respectively. Absorption was carried out three times.

\#Bactericidal activity expressed as the maximum dilution giving $90 \%$ reduction in cfu compared with corresponding controls with complement.

leucocyte responses after inoculation. As shown in the figure, infiltration by polymorphonuclear leucocytes was rather poor in control mice when challenged at late proestrous or early oestrous stages. The mean number of polymorphonuclear leucocytes in the vaginal fluid of mice at these oestrous stages was $1.5 \times 10^{\circ} / 124$ hours after inoculation, while in mice at the dioestrous stage it ranged from $50 \times 10^{9} / 1$ to $500 \times 10^{8} / 1$. In immunised mice, polymorphonuclear leucocyte response was very high regardless of the stage of oestrus at which mice were challenged, with a mean greater than $100 \times 10^{9} / 1$ vaginal fluid 24 hours after inoculation. Two distinct differences in polymorphonuclear leucocyte response between immune mice and controls were as follows: (a) responses became appreciable in immune mice as soon as 12 hours after inoculation, and (b) the level of response in immune mice became more than 10 


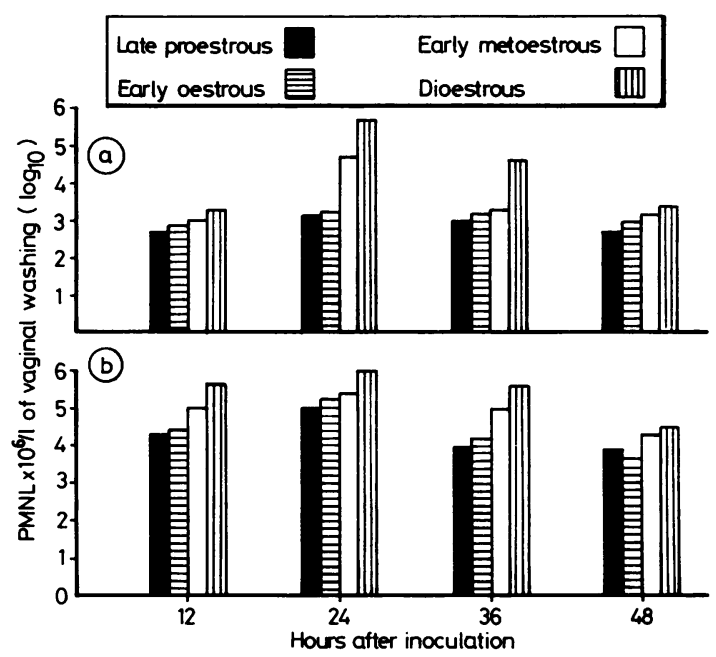

FIGURE Kinetics of vaginal leucocyte responses of $d d Y$ mice (a) controls and b) immunised mice) inoculated intravaginally with gonococci. Mice in various oestrous stages were challenged with $10^{6} \mathrm{cfu}$ strain $\mathrm{PH} 2$, and vaginal fluids were collected in $1 \mathrm{ml}$ saline. Leucocyte responses were estimated by numbers of

polymorphonuclear leucocytes (PMNL) $\left(\log _{10}\right) \times 10^{6} / l$ of fluid.

times as great as that in controls. The number of polymorphonuclear leucocytes in immune mice at the dioestrous stage was not as large 24 hours after inoculation as that in non-immune mice at the same stage.

\section{DELAYED HYPERSENSITIVITY}

Table IV shows the effect on infectivity of delayed hypersensitivity to ribosomal proteins. On days 14 and 21, when footpad responses to ribosomal proteins were maximum in immunised mice, the protection afforded was greatly enhanced. During the second to third week after immunisation, however, activity of antibody to purified ribosomal fraction in the serum of immune mice was found to be highest. These data indicated that both cellular and humoral factors contributed to mouse protection afforded by purified ribosomal fraction.

\section{Discussion}

The sensitivity to gonococcal infection in the genital tract varies between strains of mice, and the ddY strain can be the most susceptible to vaginal inoculation of gonococci. Our preliminary study showed that not only ddY but also ICR mice were susceptible to genital infection with $N$ gonorrhoeae. CF1 mice were also available for the study of gonococcal
TABLE IV Effect of delayed hypersensitivity to ribosomal proteins on mouse protection

\begin{tabular}{|c|c|c|c|}
\hline $\begin{array}{l}\text { Days after } \\
\text { immunisation }\end{array}$ & Immunogen* & $\begin{array}{l}\text { Mean (SD) } \\
\text { footpad } \\
\text { increases } \\
(\mathrm{mm}) \dagger\end{array}$ & $\begin{array}{l}\text { Protection (\%)キ } \\
\text { on day } 7\end{array}$ \\
\hline 0 & $\begin{array}{l}\text { Ribosomal } \\
\text { Saline }\end{array}$ & $\begin{array}{l}0.29(0.12) \\
0.28(0.15)\end{array}$ & $\left.\begin{array}{l}5 \\
0\end{array}\right\}$ (NS) \\
\hline 7 & $\begin{array}{l}\text { Ribosomal } \\
\text { Saline }\end{array}$ & $\begin{array}{l}0.64(0.05) \\
0.27(0.06)\end{array}$ & $\left.{ }_{5}^{35}\right\}(0.01>p>0.001)$ \\
\hline 14 & $\begin{array}{l}\text { Ribosomal } \\
\text { Saline }\end{array}$ & $\begin{array}{l}0.85(0.08) \\
0.29(0.05)\end{array}$ & $\left.{ }_{0}^{90}\right\}(p<0.001)$ \\
\hline 21 & $\begin{array}{l}\text { Ribosomal } \\
\text { Saline }\end{array}$ & $\begin{array}{l}0.92(0.06) \\
0.28(0.04)\end{array}$ & $\left.\left.\begin{array}{r}75 \\
5\end{array}\right\} p<0.001\right)$ \\
\hline
\end{tabular}
*Each group consisted of 20 mice receiving $40 \mu \mathrm{g}$ purified ribosomal
fraction or $0.2 \mathrm{ml}$ saline.

tFootpad response was measured 48 hours after an injection of antigens and expressed as the mean values of 10 mice. Data were obtained from two separate experiments $\mathbb{\Phi}$

\$The other 10 mice were challenged int strain PH2 in the late proestrous or early oestrous stages. No of mice with uterine specimens yielding negative cultures, expressed as percentage of mice studied. P values wither respect to controls (saline) were calculated by Fisher's exact test.

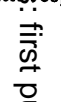

genital infection but the gesponse of polymorphonuclear leucocytes in the vagina of this mouse strain was poor compared with reactions in the other two strains. This ddY strain was originally produced in West Germany anđsimported to Japan. We have no genetic informationgon this strain, but it is very susceptible to bacterial infections such as salmonellosis and listeriosis. The्anactivity of complement in the serum of ddW ghice has not been examined in detail. The haemgyt tुic activity of whole complement for sensitised sheeperythrocytes can be measured, but the characteristicts of each component

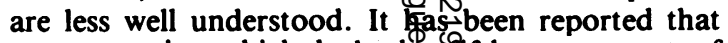
mouse strains which lack the difth component of complement $\left(\mathrm{C5}^{-}\right)$are more susceptible to gonococcal infection..$^{9}$ In this siudy we saw that the peritoneal macrophages actignted by the crude ribosomal fraction of gonocorect showed an immediate uptake of gonococci becâtse of the presence of lipopolysaccharide, unlike theo $\mathrm{C5}^{-}$macrophages which, although they were aêtifated, showed a less efficient rate of phagocytosis Because of these findings the ddY strain was not

The most important factor affecting the infectivity of the gonococcal strains usedgin this model is the preservation of the gonococciof( $\mathrm{T} 1$ or $\mathrm{T} 2$ ) by the gelatine disc method." We Gave examined 30 gonococcal strains (T1 or T2) 갯 have shown that only strains preserved by this method can survive in the mouse uterus. Strain PH2, wich was used in this study, was not different from gther T2 gonococcal strains, except that it had been preserved by the gelatine disc method since itsisolation from the patient. 
Immunisation with $40 \mu \mathrm{g}$ purified ribosomal fraction could not completely inhibit gonococcal invasion of the uterine epithelial layer, but gave $90 \%$ protection. Cooper et al ${ }^{2021}$ reported that protection against subcutaneous infection with $\boldsymbol{N}$ gonorrhoeae in guinea pigs correlated with the presence of bactericidal and agglutinating antibodies in the serum of immune animals, and that lipopolysaccharide was the major antigen responsible for the bactericidal activity seen in serum immune to ribosome. ${ }^{6}$ In the present study the ribosomal fraction was purified by affinity chromatography using antibodies to outer membrane complex conjugated to Sepharose 4B to remove contaminants that react with outer membrane proteins and lipopolysaccharides. Mouse serum with antibodies to purified ribosomal fraction did not react with gonococcal lipopolysaccharides or outer membrane complex preparations in the immunodiffusion test, and gave one major line of precipitation against purified ribosomal fraction preparation. The results of bactericidal assays have shown that vaginal fluid had higher levels of bactericidal activity than matched serum from immune mice. Samples of serum and vaginal fluid from control mice in early metoestrous or dioestrous stages had low, but detectable, bactericidal activity, although those from control mice in late proestrous or early oestrous stages had no detectable bactericidal activity.

The bactericidal activity of vaginal fluid from control mice in the dioestrous stage was comparable with that from immune mice in late proestrous or early oestrous stages. Infectivity in control mice at the dioestrous stage, however, was significantly higher than in immune mice at late proestrous or early oestrous stages, when control mice were the most susceptible to gonococcal infection. This finding indicates two possibilities. The first is that antibody to purified ribosomal fraction may serve as an opsonin and enhance the uptake of gonococci by polymorphonuclear leucocytes. Although it is uncertain whether antibodies to microsomal antigens (such as antibody to purified ribosomal fraction) can react with intact bacteria, the effect of reproductive hormones (especially progesterone) has been reported to enhance cell leakage resulting from the binding of progesterone by membrane proteins and phospholipids. ${ }^{22}$ This phenomenon may lead to the direct interaction between ribosomal substances and antiserum to purified ribosomal fraction. We based this theory on our preliminary study which showed that the incubation with progesterone of $N$ gonorrhoeae labelled with ${ }^{3} \mathrm{H}$-uracil enhanced the release of ${ }^{3} \mathrm{H}$-labelled RNA or nucleotides from cells (unpublished observation). The second possibility is that the expression of protection in the mouse may entail non-humoral defence mechanisms. In man, antigonococcal antibodies in genital secretions belong to immunoglobulin $\mathbf{G}$ and $A$, and an appreciable amount of specific IgG is produced. ${ }^{23}$ Our previous work showed that antibody to gonococcal purified ribosomal fraction was of the IgG class. ${ }^{13}$ The absorption tests showed that the higher gonococcidal activity of serum and vaginal fluid obtained from immune mice was attributable to the presence of antibody to purified ribosomal fraction. There is a great difference between the genital tract and the subcutaneous chamber in the major antigen responsible for the bactericidal activity of fluids obtained from the site of inoculation. ${ }^{6}$

Reproductive hormopes are another important humoral factor in the genital tract. The bactericidal activity of serum and Fraginal fluid obtained from mice in early metoestropis and dioestrous stages may be enhanced by the effect of progesterone, although the concentration of hormones was not measured in this study. This assumption is based on the report by Salt showing that oestrogen enhanced gonococcal growth, whereas progesterone greatly inhibited it. ${ }^{24}$ Furthermore, Rank $e \underline{t} a l$ showed that oestradiol treatment produced ch greater intensity and logger duration than in control guinea pigs. ${ }^{25}$ Previousswork in our laboratory has shown that female mice were more susceptible to genital infection wit $N$ gonorrhoeae at late proestrous or early oestrous stages, when oestrogen levels are highest. ${ }^{4}$ As onnany factors are related to hormonal activity, the cexact relation between it and defence systems in the genital tract of mice requires further study. O०

Cellular responsesoino immune mice after gonococcal inoculation were different from those in control mice. Infiltrafion of polymorphonuclear leucocytes was seen Fnuch earlier in immune mice than in control mig, 叉and immune mice showed about a hundredfoldeincrease in the total leucocyte counts in the genital 24 hours after challenge. In addition, immunisaton with purified ribosomal fraction induced detayed hypersensitivity, as measured by footpo $\mathrm{d}^{+}$responses. This could be detected one week artgr immunisation, and infectivity was greatly rechiced after delayed hypersensitivity had been ind $\overrightarrow{w c} e d$. These findings suggest a role for cellular immun in in protection of the mouse against gonococcal genilal infection. The actual contribution of delayed fypersensitivity to an early response in the genital tract of immune mice, however, is not clear in this study. This is because the chemotactic factor for polymorphonuclear leucocytes, as one of the tis cell products in a delayed hypersensitivity reaction; has not been identified, as it has for mononuclear cells. It is easier to understand 
that the rapid response of polymorphonuclear leucocytes in the genital tract of immune mice after gonococcal inoculation may be due to the chemotactic factor (C5a) produced by the complement mediated reaction, not only because of the presence of $\mathrm{C} 5$ in this mouse strain but also because there is high activity of antibody to purified ribosomal factor in the serum of immune mice.

Although there ate some questions about immunity to gonococcal infection in the genital tract of mice immunised with purified ribosomal fraction, this study shows that an early polymorphonuclear leucocyte response mediated by antibody and complement interaction can reduce infectivity, and that the reproductive hormones may be responsible for enhancing gonococcidal activity in serum and vaginal fluid. IgG antibody to purified ribosomal factor is present in vaginal secretion and plays an important part in gonococcidal activity in the genital tract. Thus the major factor in defence mechanisms of the genital tract is very different from those of the subcutaneous chamber. This difference indicates that studies on infection with and immunity to $N$ gonorrhoeae should concentrate on the genital tract because the subcutaneous chamber is not the natural site of infection with $N$ gonorrhoeae.

Studies are in progress to identify the mechanisms by which antibody to purified ribosomal fraction kills gonococci, the active moiety of purified ribosomal fraction, and the effect of reproductive hormones on the defence systems against gonococcal infection in the genital tract.

\section{References}

1. Arko RJ. Neisseria gonorrhoeae: experimental infection of laboratory animals. Science 1972; 177:1200-1.

2. Faster RS, Vinson JW. Chicken embryo as an animal model for gonorrhea. Infect Immun 1977; 16:568-74.

3. Lucas CT, Chandler F Jr, Martin JE Jr, Schmale JD. Transfer of gonococcal urethritis from man to chimpanzee. An animal model for gonorrhea. JAMA 1971;216:1612-4.

4. Kita E, Matsuura H, Kashiba S. A mouse model for the study of gonococcal genital infection. J Infect Dis 1981;143:67-70.

5. Turner WH, Novotony P. The inability of Neisseria gonorrhoeae pili antibodies to confer immunity in subcutaneous guinea pig chambers. J Gen Microbiol 1976;92:224-8.

6. Wannemuehler JM, Miller RD, Cooper MD. Characterization of the immune response in subcutaneous chambers of guinea pigs immunized with a ribosomal preparation from Neisseria gonorrhoeae. Infect Immun 1982;37:469-73.
7. Hilton AL, Richmond SJ, Milne JD, Hindley F, Clarke SKR. Chlamydia $A$ in the female genital tract. Br J Vener Dis 1974; 50: $1-9$.

8. Allen $\mathrm{E}$. The oestrous cycle in the mouse. Am J Anat 1922; 30: 297-349.

9. Thung PH, Boot LM, Muhlbock $O$. Senile changes in the oestrous cycle and ovarian structure in some inbred strains of mice. Acta Endocrinol (Copenh) 1956; 23:8-32.

10. Kellog DS Jr, Peacock WL, Deacon WE, Brown L, Pirkle CI. Neisseria gonorrhoeae. I. Virulence genetically linked to clonal variation. J Bacteriol 1963;85: 1274-9.

11. Yamai S, Obara Y, Nikkawa T, Shimoda Y, Miyamoto Y. Preservation of Neisseria gonorrhoeae by the gelatin-disc method. Br J Vener Dis 1979;55:90-3.

12. Kita E, Kashiba S. Immunogenicity of the ribosomal fraction of Salmonella typhimurium: analysis of humoral immunity. Infect Immun 1980; 27: 197-203.

13. Kita E, Kashiba S. Passive hemagglutination test for detection of antibody to gonococcal ribosomal antigen in sera from patients with asymptomatic gonorrega. J Clin Microbiol 1982; 15:558-676.

14. Karkhanis VK, Anderson RL, Zekner JY, Carlo DJ, Stoudt TH. Antigenic polypeptide complex from the Melvin strain of Neisseria gonorrhoeae: isolation andie properties. Infect Immun 1979;25:635-44.

15. Wolf-Watz H, Normark S, Bloom GD. Rapid method for isolation of large quantities of outer membrane from Escherichia coli $\mathrm{K}-12$ and its application to the study of envelope mutants. J Bacteriol 1973:115: 1191-7.

16. Brinton CC, Bryan J, Dillon JA, et control: role of bacterial pili in-disease, purification and properties of gonococcal pili, and 亜ogress in the development of a gonococcal pilus vaccine for gonorrhea. In: Brooks GF, Gotschlich EC, Holmes KK, Sawger WD, Young FE, eds. Immunobiology of Neisseria gono hoeae. Washington, DC: American Society for Microbiolog $1978: 155-78$.

17. Westphal O, Jan K. Bacterial lipopolysaccharides. Methods in Carbohydrate Chemistry 1965;5:8

18. Fogel S, Sypherd PS. Extraction and isolation of individual ribosomal proteins from Escherich B̈ coli. J Bacteriol 1968;96: 358-64.

19. Cooper MD, Floyd SA. In vitro kinetics of phagocytosis and intracellular killing of gonococci peritoneal macrophages from mice deficient in complentent component 5 . Infect Immun 1982;36:363-70.

20. Cooper MD, Tewari RP, BowsersD. Immunogenicity of ribosomal preparations from Neiseria gonorrhoeae. Infect Immun 1980;28:92-100. $\underset{<}{*}+$

21. Cooper MD, Wannemuehler MQ Miller RD, Fedyk MF. Role of outer envelope contaminat on in protection elicited by ribosomal preparations againston Neisseria gonorrhoeae infection. Infect Immun 1981;32:173-9.

22. Morse SA, Fitzgerald TJ. Effectlof progesterone on Neisseria gonorrhoeae. Infect Immun 1976; 10: 1370-7.

23. Tramont CE, Ciak J. Antigon ceccal antibodies in genital secretions. In: Brooks GF, Gots WD, Young FE, eds. Immund blogy of Neisseria gonorrhoeae. Washington DC: AmerfantSociety for Microbiology, 1978:274-8.

24. Salt IE. The differential susceptibifity of gonococcal opacity variants to sex hormones. Can DMficrobiol 1982; 28:301-6.

25. Rank RG, White HJ, Hough Jr, Pasley JN, Barron AL. Effect of estradiol on chlamydial genimi infection of female guinea pigs. Infect Immun 1982; 38:69037 